\title{
Effect of Water Spinach Floating Bed and Chlorella pyrenoidosa on Water Quality and Shrimp Growth in an Aquaponics System
}

\author{
Mei Liu, Julin Yuan, Meng Ni, Zhimin Gu* \\ Agriculture Ministry Key Laboratory of Healthy Freshwater Aquaculture, \\ Key Laboratory of Fish Health and Nutrition of Zhejiang Province, \\ Zhejiang Institute of Freshwater Fisheries, Huzhou 313001, China
}

Received: 28 September 2020

Accepted: 14 May 2021

\begin{abstract}
Twelve concrete ponds were stocked with pacific white shrimp (Penaeus vannamei) each weighing about $0.1 \mathrm{~g}$ and grown for 77 days. The effects of autotrophs, floating beds of water spinach (Ipomoea aquatica) and microalgae (Chlorella pyrenoidosa) on water purification and shrimp growth were assessed. The results showed that the water quality of aquaculture water with water spinach (S1), aquaculture water with chlorella (S2), and aquaculture water with water spinach and chlorella (S3) were significantly better than that of Aquaculture water without vegetation and chlorella (S0). The combination of water spinach and chlorella (S3) was able to keep ammonia and nitrite nitrogen levels below $1.0 \mathrm{mg} / \mathrm{L}$ and $0.1 \mathrm{mg} / \mathrm{L}$, respectively. These low levels were not lethal or detrimental to the growth of the white shrimp. The roots of the water spinach were the vital organs for the removal of $\mathrm{N}$ and P. Sixty percent of the removed portion of $\mathrm{N}$ and $\mathrm{P}$ accumulated in the roots of the water spinach. The survival rate and mean harvest weight of shrimp from S1, and S3 was significantly higher than that from S0, and S2. In addition, in S3 the immunity of the shrimp was improved due to the formation of similar biological floccules around the roots and thus increasing their survival rate. The present study indicates that a vegetable-microalgae-shrimp system has a good potential for practical application in commercial shrimp production.
\end{abstract}

Keywords: vegetable-microalgae-shrimp, water quality, nutrient recycling, immune enzymes, biological floccules 


\section{Introduction}

Intensive shrimp production is expanding rapidly in most Asian countries and especially in China. China is currently the largest shrimp producer in the world with a production capacity of about $30-40 \%$ of the total [1]. In 2016, demand for shrimp for local consumption increased by about $1700 \mathrm{kt}$ [2]. However, from 2012 to 2016, the total production of shrimp decreased from $1580 \mathrm{kt}$ to $750 \mathrm{kt}$. This was because the survival rate of the shrimp had decreased to about $20 \%$ in 2016 and was despite the increase in the breeding area. The low survival rate of the shrimp was mainly caused by the poor quality of the water [3].

Thakur and Lin [4] revealed that shrimp could only assimilate $23 \%-31 \%$ nitrogen $(\mathrm{N})$ and $10 \%-13 \%$ phosphorus $(\mathrm{P})$ of the total inputs into the shrimp ponds. Consequently, the water quality in the shrimp ponds deteriorates because the levels of nutrients such as $\mathrm{N}$ and $\mathrm{P}$ progressively increase over the culture period due to the accumulation of excess shrimp food and excretory products [5]. The poor water quality of shrimp ponds is characterized by large amounts of $\mathrm{N}$ and $\mathrm{P}$ [6]. It also potentially causes serious environmental impacts such as eutrophication [7], which increases the risk of disease outbreaks [8]. Therefore, to maintain good water quality and improve the survival rate of the shrimp, phytoremediation using especially floating beds of aquatic plants, also called aquaponics, is currently attracting much attention. This is because it is low cost, non-intrusive, environmentally friendly, and safe [9].

Many species of fish (e.g., Oreochroms mossambcus, Micropterus salmoides) and plants (e.g., Lactuca sativa, okra, Solanum lycopersicum) have been assessed for their practical application in aquaponics [10]. However, there have only been a few studies on the application of aquatic plants in shrimp aquaculture. In addition, an in-depth study of nutrient transformations in aquaponics (shrimp and plants) is still lacking. There are very few studies on the effects of floating beds of water spinach (Ipomoea aquatica) on the growth of shrimp. Microalgae, such as Chlorella pyrenoidosa, Scenedesmus obliquus, Ocoystis borgei and Chlamydomonas also play a vitally important role in the process of breeding shrimp [11]. Worldwide, $C$. pyrenoidosa has been used in shrimp ponds to regulate the quality of the water and was selected for use in the plant-shrimp system in the present study.

To investigate the relationship between and effects of water spinach and chlorella (microalgae) on water quality and the growth of shrimp, a study of shrimp aquaculture lasting 77 days was conducted in concrete shrimp ponds. Shrimp production, plant growth and nutrient uptake were analyzed. The results of the present study were used to design an efficient shrimp aquaponic system that uses water spinach and chlorella to maintain water quality.

\section{Materials and Methods}

\author{
Experimental Setup
}

A series of batch mesocosm experiments were conducted from July to September 2018 in Huzhou $\left(\mathrm{E} 120^{\circ} 04^{\prime}, \mathrm{N} 20^{\circ} 52^{\prime}\right)$, a representative city in Southeast China. The experiments were carried out in twelve $6 \mathrm{~m}^{3}$ concrete ponds (length $3.0 \mathrm{~m} \times$ width $2.0 \mathrm{~m} \times$ depth $1.0 \mathrm{~m})$. Each pond was covered with transparent glass that excluded rainwater but created an environment in which the light and temperature conditions would be similar to that in the field. Distilled water was added daily to the shrimp ponds to replenish water loss due to evaporation, transpiration, and sampling. The ecological floating bed was constructed with PVC pipes as the frame (length $1.5 \mathrm{~m} \times$ width $1.0 \mathrm{~m}$ ) and with nylon net (grid diameter $2 \mathrm{~cm}$ ) as the carrier of the water spinach. According to previous research [12-13], aquatic plants that cover $20 \% \sim 30 \%$ of the surface area of the water achieved the purpose of water purification without affecting the transparency of the water bodies. Therefore, at the start of the present study the ecological floating beds covered $25 \%$ of the surface area of the water.

\section{Experiment Conditions}

There were four treatment groups with S0aquaculture water without vegetation and chlorella, S1aquaculture water with water spinach, S2-aquaculture water with chlorella, S3-aquaculture water with water spinach and chlorella, respectively. And each treatment had three replications. The raw aquaculture water was taken from shrimp ponds. The water quality of the raw water was shown in Table 1 (three parallel samples were monitored for each treatment). About 360 shrimp with initial mean weight $0.1 \mathrm{~g}( \pm 0.0087, \mathrm{SD})$ were put into each concrete pond to reach the stocking density which was consistent with that of actual production in China (sixty per $\mathrm{m}^{3}$ ). Shrimp were fed with $5 \%$ of its body weight per day with commercial shrimp feed composed of $40 \%$ crude protein, $21.2 \%$ carbohydrate, $6 \%$ crude fat, $6.2 \%$ crude fiber, $11.0 \%$ moisture, $15.3 \%$ ash and $0.8 \%$ phosphorus. In order to achieve better plant growth, $500 \mathrm{~mL}$ Hoagland microelement solution was added into aquaponics system to provide minerals which were essential for plant growth. The initial fresh weight of water spinach was $1.0 \mathrm{~kg} / \mathrm{m}^{2}$ for $\mathrm{S} 1$ and $\mathrm{S} 3$. $2000 \mathrm{~mL}$ culture solution of Chlorella pyrenoidosa was poured into the shrimp ponds every two weeks and the initial density of culture solution was about $10^{8}$ cell/ L.

\section{Sampling and Analyses}

Every seven days, water samples were obtained from each shrimp pond after feeding and were immediately analyzed for $\mathrm{TN}, \mathrm{TP}, \mathrm{NH}_{4}^{+}-\mathrm{N}, \mathrm{NO}_{3}^{-}-\mathrm{N}, \mathrm{NO}_{2}^{-}-\mathrm{N}$ and $\mathrm{COD}_{\mathrm{Mn}}$, using $\mathrm{HACH}$ reaction kits (Loveland, $\mathrm{CO}$, 
Table 1. The characteristic of the raw water.

\begin{tabular}{|c|c|}
\hline Components & Concentration \\
\hline Temperature $\left({ }^{\circ} \mathrm{C}\right)$ & $29.0 \pm 0.51^{\#}$ \\
\hline Salinity $(\%)$ & $4.00 \pm 0.11$ \\
\hline $\mathrm{pH}$ & $8.36 \pm 0.32$ \\
\hline $\mathrm{DO}(\mathrm{mg} / \mathrm{L})$ & $7.90 \pm 0.29$ \\
\hline Total ammonia $\mathrm{NH}_{4}{ }^{+}-\mathrm{N}(\mathrm{mg} / \mathrm{L})$ & $0.06 \pm 0.01$ \\
\hline Nitrate $\mathrm{NO}_{3}{ }^{-} \mathrm{N}(\mathrm{mg} / \mathrm{L})$ & $0.71 \pm 0.052$ \\
\hline Nitrite $\mathrm{NO}_{2}-\mathrm{N}(\mathrm{mg} / \mathrm{L})$ & $0.006 \pm 0.008$ \\
\hline $\mathrm{COD}_{\mathrm{Mn}}(\mathrm{mg} / \mathrm{L})$ & $38.0 \pm 1.2$ \\
\hline Chlorophyll a $\mathrm{Chla}(\mathrm{mg} / \mathrm{L})$ & $0.377 \pm 0.056$ \\
\hline Total nitrogen $\mathrm{TN}(\mathrm{mg} / \mathrm{L})$ & $2.23 \pm 0.14$ \\
\hline Total phosphorus TP $(\mathrm{mg} / \mathrm{L})$ & $0.277 \pm 0.047$ \\
\hline
\end{tabular}

${ }^{*}$ Values are means of replicates \pm standard deviation (mean $\pm \mathrm{SD})$.

USA). In addition, DO, water temperature, $\mathrm{pH}$ and Chla were measured in situ weekly using SEBA KLL-Q-2 Portable Water Quality Probes (Gewerbestr, CO, Germany). Once a month, water spinach was carefully harvested from each floating bed and gently washed with tap water and the respective mass of the fresh roots, leaves and stems immediately determined. The respective biomass of the roots, leaves and stems were determined after they were dried to a constant weight for $48 \mathrm{~h}$ in a fan-circulated oven at $80^{\circ} \mathrm{C}$. The $\mathrm{N}$ content of the leaves, stems, and roots of the water spinach, and detritus were determined using a LECO TruSpec C/N analyzer (LECO Corp., St. Joseph, MI, USA). The leaves, stems, and roots of the water spinach, and detritus were digested and then the $\mathrm{P}$ content was measured using vanadium molybdenum yellow colorimetry.

Simultaneously, the weight and length of 30 white shrimp randomly sampled from each group, were measured. The survival rate, rate of weight gain, and specific growth rate were subsequently calculated. The hepatopancreas was collected from three white shrimp randomly selected from each group, and used to measure the activities of the immune enzymes superoxide dismutase (SOD), catalase (CAT), glutathione reductase (GR), glutathione (GSH), glutathione S-transferase (GST) and peroxidase (POD) with commercial kits (Nanjing Jiancheng Bioengineering Institute, Nanjing, China).

\section{Statistical Analysis}

Statistical analyses were performed using the software Statistical Package for the Social Sciences (SPSS, v. 13.0). Data were tested for normality using the Shapiro-Wilk goodness-of-fit test. Tukey's or Dunn's
Table 2. The fresh and dry weight of leaf, stem and root from water spinach.

\begin{tabular}{|c|c|c|c|}
\hline Index & Organs & $\mathrm{S} 1$ & $\mathrm{~S} 3$ \\
\hline \multirow{4}{*}{$\begin{array}{c}\text { Fresh weight } \\
(\mathrm{kg})\end{array}$} & Leaf & $12.1 \pm 1.2^{\#}$ & $11.20 \pm 0.92$ \\
\cline { 2 - 4 } & Stem & $3.30 \pm 0.75$ & $3.10 \pm 0.80$ \\
\cline { 2 - 4 } & Root & $3.50 \pm 0.92$ & $3.6 \pm 0.93$ \\
\cline { 2 - 4 } & Total & $18.9 \pm 1.1$ & $17.9 \pm 1.6$ \\
\hline \multirow{4}{*}{ Dry weight $(\mathrm{kg})$} & Leaf & $0.55 \pm 0.024$ & $0.51 \pm 0.022$ \\
\cline { 2 - 4 } & Stem & $0.24 \pm 0.013$ & $0.25 \pm 0.013$ \\
\cline { 2 - 4 } & Root & $0.711 \pm 0.041$ & $0.70 \pm 0.042$ \\
\cline { 2 - 4 } & Total & $1.50 \pm 0.075$ & $1.46 \pm 0.086$ \\
\hline
\end{tabular}

"Values are (mean $\pm \mathrm{SD})$ and the values represent total

biomass yield. The same as bellows.

test were performed. The former parametric test was used when the normality assumption was accepted; the latter, nonparametric test was used when normality could not be assumed. Then significant comparison was made between the two treatment groups at a significant level of $P<0.05$.

\section{Results and Discussion}

\section{Growth Characteristics of the Plants}

Plant growth is another criterion used to assess the suitability of aquaponics recirculation systems [12]. The fresh and dry weight of the leaves, stems, and roots of the water spinach are summarized in Table 2. The results indicate that the plants in all of the replicates grew well and no significant differences were detected between treatments $\mathrm{S} 1$ and $\mathrm{S} 3(P>0.05)$. The results summarized in Table 3 demonstrate that $\mathrm{N}$ and $\mathrm{P}$ bioaccumulated in the different parts of the water spinach and consequently the rates at which $\mathrm{N}$ and $\mathrm{P}$ were removed from the water by the plants were also measured.

The water spinach planted in treatments S1, and S3 grew robustly on the floating mats, with extensive development of the roots which constituted more than $50 \%$ of the total biomass of the plants (Table 2). The $\mathrm{N}$ content of the roots was significantly higher than those of the leaves $(P<0.05)$. The roots of the water spinach were therefore the vital organ of $\mathrm{N}$ and $\mathrm{P}$ accumulation, with had the highest removal rates of about $65.6 \%$ and $64.1 \%$ in S1, respectively, as well as $67.3 \%$ and $67.0 \%$ in S2, respectively (Table 3). Similar results have been obtained in studies using many other plant species [13]. For example, Wang found that the roots of pickerelweed and softstem bulrush which constituted $50-70 \%$ of total plant biomass, were the dominant tissue responsible for $\mathrm{N}$ and $\mathrm{P}$ removal. In the present study, plant uptake of $\mathrm{N}$ and $\mathrm{P}$ could not be considered to be the dominant 
Table 3. $\mathrm{N}$ and $\mathrm{P}$ assimilation by leaf, stem and root of water spinach.

\begin{tabular}{|c|c|c|c|c|}
\hline Organs & N content $(\mathrm{mg} / \mathrm{g})$ & P content $(\mathrm{mg} / \mathrm{g})$ & N removal $(\mathrm{g})$ & P removal $(\mathrm{g})$ \\
\hline S1-Dry leaf & $20.41 \pm 1.6^{\mathrm{a}^{*}}$ & $2.44 \pm 0.11^{\mathrm{a}}$ & $12.6 \pm 1.1^{\mathrm{a}}$ & $1.39 \pm 0.16^{\mathrm{a}}$ \\
\hline S3-Dry leaf & $20.36 \pm 1.5^{\mathrm{a}}$ & $2.48 \pm 0.12^{\mathrm{a}}$ & $11.8 \pm 1.0^{\mathrm{b}}$ & $1.55 \pm 0.13^{\mathrm{a}}$ \\
\hline S1-Dry stem & $23.23 \pm 1.5^{\mathrm{ab}}$ & $2.51 \pm 0.11^{\mathrm{ab}}$ & $5.75 \pm 0.58^{\mathrm{c}}$ & $0.65 \pm 0.13^{\mathrm{b}}$ \\
\hline S3-Dry stem & $23.25 \pm 1.51^{\mathrm{ab}}$ & $2.49 \pm 0.09^{\mathrm{ab}}$ & $5.81 \pm 0.53^{\mathrm{c}}$ & $0.67 \pm 0.14^{\mathrm{b}}$ \\
\hline S1-Dry root & $25.42 \pm 1.42^{\mathrm{b}}$ & $2.74 \pm 0.14^{\mathrm{b}}$ & $16.24 \pm 1.23^{\mathrm{d}}$ & $2.16 \pm 0.13^{\mathrm{c}}$ \\
\hline S3-Dry root & $24.28 \pm 1.40^{\mathrm{b}}$ & $2.77 \pm 0.15^{\mathrm{b}}$ & $15.66 \pm 1.10^{\mathrm{d}}$ & $2.13 \pm 0.15^{\mathrm{c}}$ \\
\hline
\end{tabular}

${ }^{*}$ Different superscripts in the same column indicate significant difference $(P<0.05)$.

removal mechanism in the aquaponics system. In addition, the inclusion of water spinach decreased the detritus which included residue from the feed and shrimp excrement, etc., and thus, to some extent, improved the quality of the water.

\section{Shrimp Growth and Immune Enzymes}

The average weight of the shrimp decreased from $\mathrm{S} 3>\mathrm{S} 2>\mathrm{S} 1>\mathrm{S} 0$ and the average survival rate was $\mathrm{S} 1>\mathrm{S} 3>\mathrm{S} 2>\mathrm{S} 0$ as shown in Table 4 . The weight gain rate and specific growth rate of the shrimp in S3 were significantly higher than in the other three treatments $(P<0.05)$. The results showed that including water spinach or chlorella each resulted in an improvement in the growth of the pacific white shrimp. However, the best improvement in the growth of the shrimp was achieved with a combination of chlorella and water spinach.

Many studies determined that Chlorella pyrenoidosa is rich in protein and a variety of trace elements (such as $\mathrm{Fe}, \mathrm{Cu}$, Se, etc.) and can be used as a very good auxiliary feed and can be fed directly to shrimp. The water spinach developed a root system as shown in Fig. 1. The mass of roots beneath the floating mats provide a safe shelter for shrimp shedding their exoskeleton which can contribute to improving their survival rates [14]. In the photomicrograph of roots, there were more chlorella as well as Protozoa like Daphnia magna, Paramecium, etc. around the roots of the water spinach in S1 than S3 (Fig. 1). In addition, gummy mucus around the roots can be clearly seen. The mucus was favorable to the formation of biofloc which consisted of beneficial bacteria, microalgae, protozoa as well as organic detritus around the roots [15]. Many studies have reported that biofloc composed of a diverse microbial community, plays important roles in natural productivity, water quality, nutrient cycling and serves as a complementary source of food for farmed animals [16], especially shrimp [17].

To further explore changes in the physiology of shrimp, the following physiological and biochemical indices, SOD, CAT, GST, GR, POD, and the content of the GSH were determined (Table 5.). Compared with the control group S0, the activities of the enzymes of the immune system of the shrimp in treatments $\mathrm{S} 1$, $\mathrm{S} 2$, and S3 were significantly improved $(P<0.05)$, with the exception of the CAT activity. In addition, the activities of the enzymes of the shrimp from treatment S3 were the highest, followed by S1, S2, and S0. The GSH content of the hepatopancreas of the shrimp in S3 was significantly higher than those from treatments S0, S1, and S2 $(P<0.05)$. Therefore, good conditions enhanced the activities of the enzymes involved in the immunity of the shrimp and contributed to reducing their mortality rate [18]. This was especially true for the shrimp in treatment S3, the combination of water spinach and chlorella.

\section{Changes in Water Quality}

The changes in the quality of the aquaculture water were presented in Figs 2 and 3. The levels of $\mathrm{TN}, \mathrm{NO}_{3}^{-}$ $-\mathrm{N}, \mathrm{TP}$ and $\mathrm{COD}_{\mathrm{Mn}}$ of the aquaculture water in $\mathrm{S} 0$ were

Table 4. The growth characteristic of Penaeus vannamei among the four treatments.

\begin{tabular}{|c|c|c|c|c|}
\hline Index & S0 & S1 & S2 & S3 \\
\hline Average weight (g) & $2.03 \pm 0.09^{\mathrm{a}^{\mathrm{a}}}$ & $2.13 \pm 0.15^{\mathrm{a}}$ & $2.45 \pm 0.13^{\mathrm{ab}}$ & $2.51 \pm 0.26^{\mathrm{b}}$ \\
\hline Average length (cm) & $7.43 \pm 0.17^{\mathrm{a}}$ & $7.55 \pm 0.21^{\mathrm{a}}$ & $7.94 \pm 0.36^{\mathrm{ab}}$ & $8.30 \pm 0.41^{\mathrm{b}}$ \\
\hline Survival rate (\%) & $73.3 \pm 15.6^{\mathrm{a}}$ & $93.3 \pm 12.4^{\mathrm{b}}$ & $74.0 \pm 10.8^{\mathrm{a}}$ & $80.0 \pm 15.3^{\mathrm{b}}$ \\
\hline Weight gain rate (\%) & $764.5 \pm 73.2^{\mathrm{a}}$ & $841.4 \pm 127.6^{\mathrm{a}}$ & $793.6 \pm 108.1^{\mathrm{a}}$ & $1160.7 \pm 221.2^{\mathrm{b}}$ \\
\hline Specific growth rate (\%) & $4.08 \pm 0.12^{\mathrm{a}}$ & $4.19 \pm 0.20^{\mathrm{a}}$ & $4.25 \pm 0.20^{\mathrm{a}}$ & $4.61 \pm 0.24^{\mathrm{b}}$ \\
\hline
\end{tabular}

"Different superscripts in the same row indicate significant difference $(P<0.05)$. The same as bellows. 


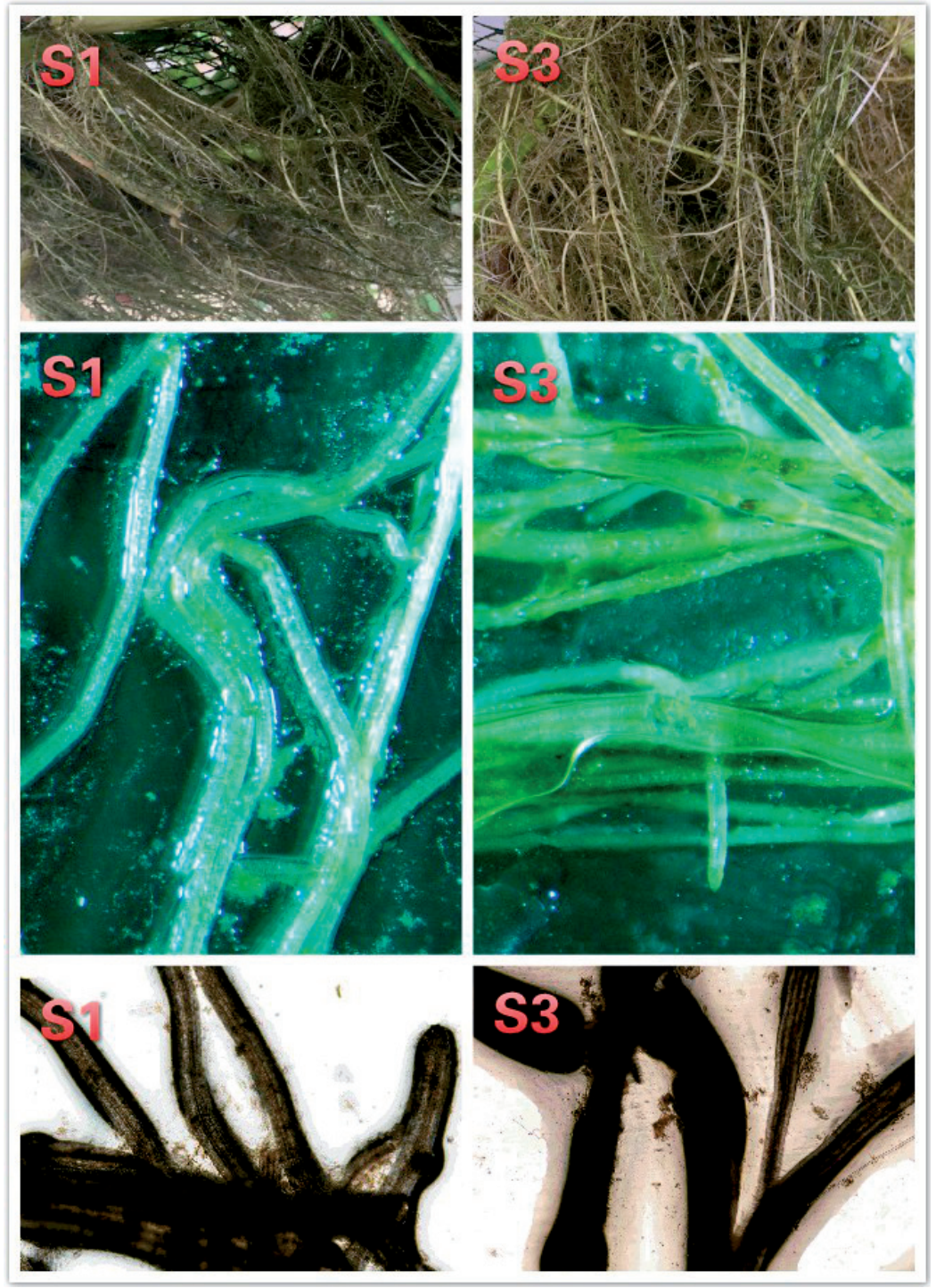

Fig. 1. The photomicrograph of roots from the treatment S1 and S3.

significantly higher than those of treatments S1, S2 and S3, and especially at the end of the experiment. This was mainly due to the accumulation of excess feed and excretory products in the water. In S0, the $\mathrm{NH}_{4}^{+}-\mathrm{N}$ concentration initially increased sharply then declined slightly but the level remained high. The concentration of $\mathrm{NH}_{4}^{+} \mathrm{-N}$ in the other three treatments was lower but followed a similar pattern to the changes in $\mathrm{S} 0$. In contrast, the $\mathrm{NO}_{2}^{-}-\mathrm{N}$ concentration of $\mathrm{S} 0$ sharply increased to $0.254 \mathrm{mg} / \mathrm{L}$ on day 77 of the experiment. Since this concentration was lethal to shrimp, the experiment was terminated.

The nitrifying and denitrifying bacteria etc. in the water column continuously converted the $\mathrm{NH}_{4}^{+}-\mathrm{N}$ and

Table 5. Changes in the activities of immune enzymes among the four treatments.

\begin{tabular}{|c|c|c|c|c|}
\hline Index & S0 & S1 & S2 & S3 \\
\hline SOD (U/mg prot) & $63.77 \pm 4.87^{\mathrm{a}}$ & $113.05 \pm 10.26^{\mathrm{b}}$ & $96.95 \pm 6.51^{\mathrm{b}}$ & $116.84 \pm 9.38^{\mathrm{b}}$ \\
\hline CAT(U/mg prot) & $0.38 \pm 0.09^{\mathrm{a}}$ & $0.47 \pm 0.11^{\mathrm{a}}$ & $0.43 \pm 0.09^{\mathrm{a}}$ & $0.55 \pm 0.18^{\mathrm{b}}$ \\
\hline GST (U/mg prot) & $59.57 \pm 11.24^{\mathrm{a}}$ & $129.83 \pm 7.61^{\mathrm{b}}$ & $109.02 \pm 20.17^{\mathrm{b}}$ & $119.52 \pm 15.3^{\mathrm{b}}$ \\
\hline GR (U/g prot) & $3.01 \pm 0.32^{\mathrm{a}}$ & $3.21 \pm 0.18^{\mathrm{b}}$ & $3.56 \pm 0.54^{\mathrm{b}}$ & $4.56 \pm 0.33^{\mathrm{b}}$ \\
\hline POD (U/g prot) & $1.77 \pm 0.40^{\mathrm{a}}$ & $2.91 \pm 0.11^{\mathrm{b}}$ & $3.02 \pm 0.16^{\mathrm{b}}$ & $3.22 \pm 0.14^{\mathrm{b}}$ \\
\hline GSH (mg/g prot) & $31.55 \pm 5.42^{\mathrm{a}}$ & $40.36 \pm 7.29^{\mathrm{a}}$ & $38.24 \pm 4.44^{\mathrm{a}}$ & $45.65 \pm 3.88^{\mathrm{b}}$ \\
\hline
\end{tabular}



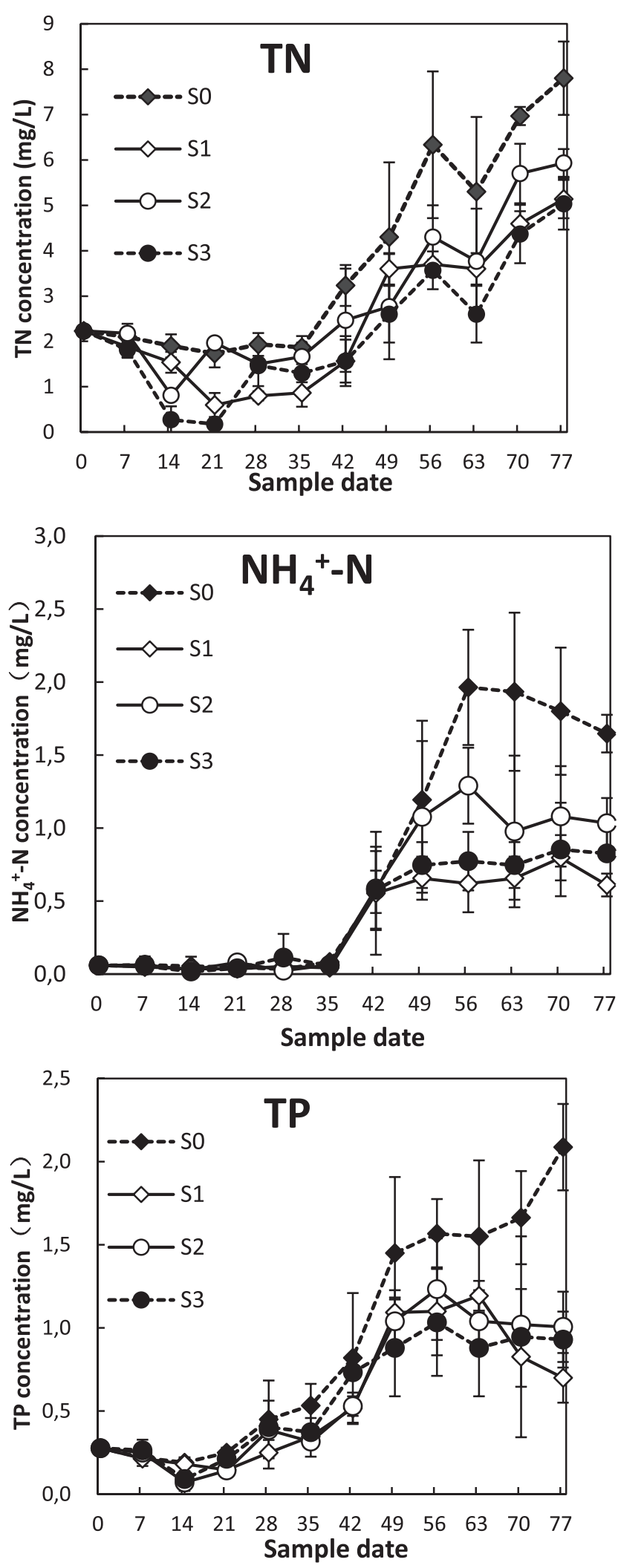
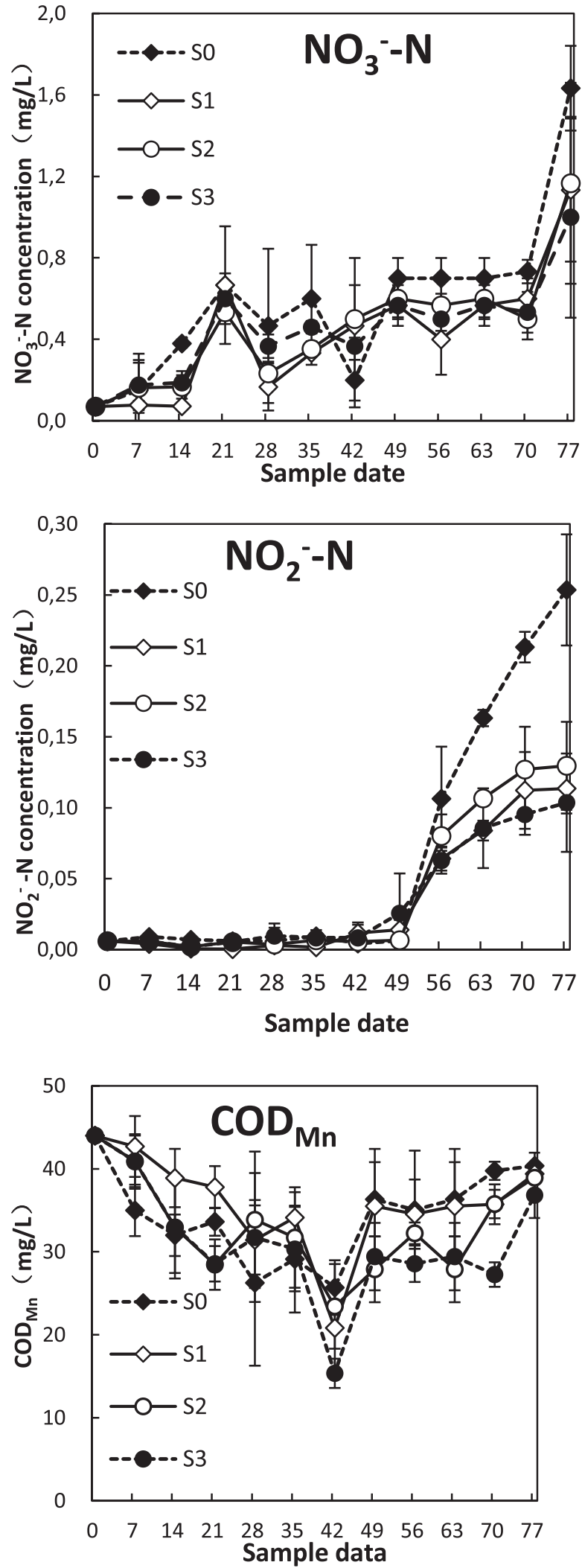

Fig. 2. $\mathrm{TN}, \mathrm{NO}_{3}^{-}-\mathrm{N}, \mathrm{NH}_{4}^{+}-\mathrm{N}, \mathrm{NO}_{2}^{-}-\mathrm{N}$ TP and $\mathrm{COD}_{\mathrm{Mn}}$ concentration for different treatments.

$\mathrm{NO}_{2}^{-}-\mathrm{N}$ to $\mathrm{NO}_{3}^{-}-\mathrm{N}, \mathrm{N}_{2}, \mathrm{~N}_{2} \mathrm{O}$, etc. Consequently, the concentrations of $\mathrm{NH}_{4}^{+}-\mathrm{N}$ and $\mathrm{NO}_{2}^{-}-\mathrm{N}$ in the water were very low at $0.1 \mathrm{mg} / \mathrm{L}$ and $0.02 \mathrm{mg} / \mathrm{L}$, respectively. However, because of the rapid growth of the shrimp and the accumulation of residual feed, the concentration of $\mathrm{NH}_{4}^{+}-\mathrm{N}$ and $\mathrm{NO}_{2}^{-}-\mathrm{N}$ increased sharply after 35 and 42 days. Nevertheless, the water quality of treatments $\mathrm{S} 1, \mathrm{~S} 2$ and S3 was still better than that of S0. This 

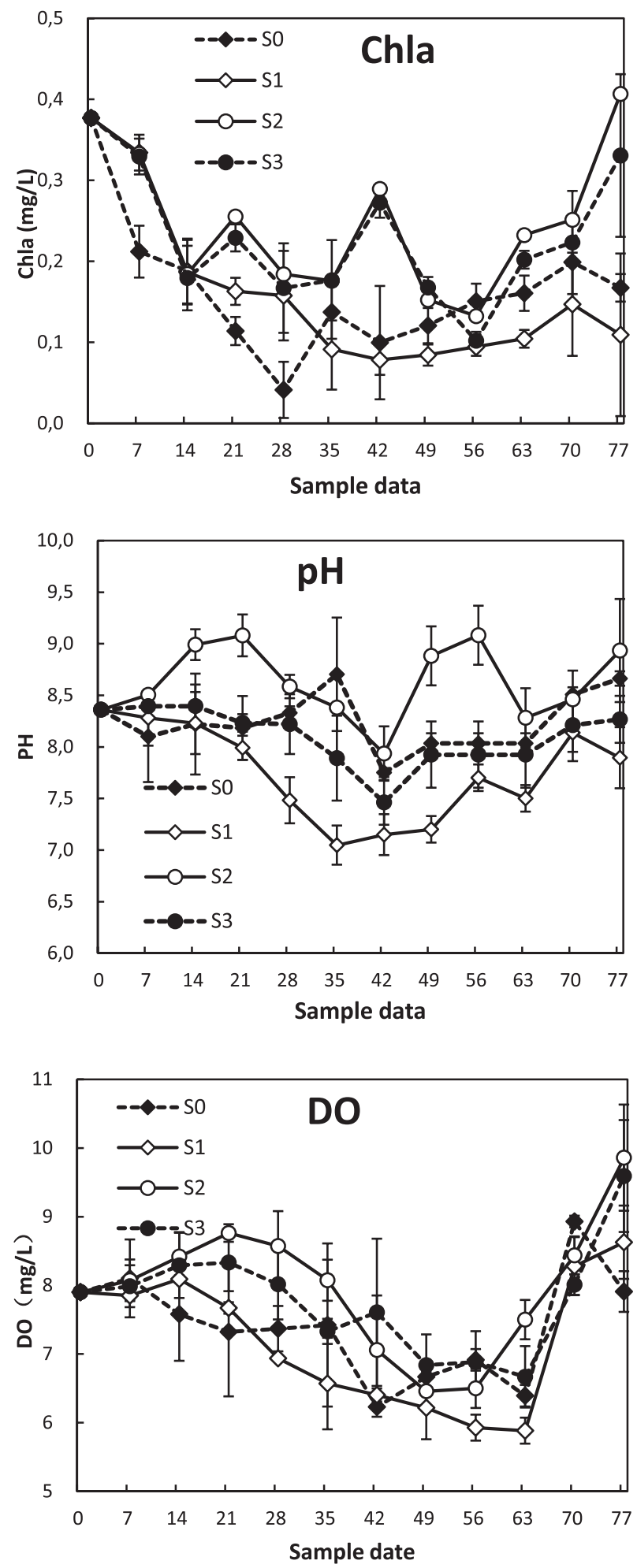

Fig. 3. Chla, $\mathrm{pH}$ and DO concentration variation in different treatments.

was particularly true for S3 which indicates that the combination of water spinach and chlorella can maintain relatively low levels of $\mathrm{NH}_{4}{ }^{+}-\mathrm{N}$ and $\mathrm{NO}_{2}^{-}-\mathrm{N}$ that were not detrimental to the growth of the white shrimp $[19,20]$. However, the concentration of $\mathrm{NO}_{3}^{-}-\mathrm{N}$ did not rapidly increase, and a plausible reason may be the preferential utilization of it by the plants. Inselsbacher et al. [21] used a stable isotope of nitrogen $\left({ }^{15} \mathrm{~N}\right)$ to explore the $\mathrm{NO}_{3}^{-}-\mathrm{N}$ and $\mathrm{NH}_{4}^{+}-\mathrm{N}$ uptake rates of plants and the results showed that the uptake rate of $\mathrm{NO}_{3}{ }^{-} \mathrm{N}$ was the highest. However, the preference for $\mathrm{NO}_{3}^{-}-\mathrm{N}, \mathrm{NO}_{2}^{-}-\mathrm{N}$ and $\mathrm{NH}_{4}^{+}-\mathrm{N}$ uptake was dependent on their concentrations, the growing stage of the plant, and genetic factors [22]. Hence, the preferential uptake of $\mathrm{NH}_{4}^{+}-\mathrm{N}$ and $\mathrm{NO}_{2}^{-}-\mathrm{N}$ by plants should be facilitated in aquaponics systems because $\mathrm{NO}_{3}^{-}-\mathrm{N}$ is not toxic to fish or shrimp even at high concentration above $50 \mathrm{mg} / \mathrm{L}$.

The Chla, $\mathrm{pH}$ and $\mathrm{DO}$ of the aquaculture water were to different extents affected by the presence of the components of the FTWs. Chla, $\mathrm{pH}$ and DO in the water column varied markedly among the treatments. The DO was slightly reduced in the control group $\mathrm{S} 0$ because of the death of the microalgae. The average content of the DO in the treatments with water spinach was the lowest because of respiration by its roots. The level of DO was the highest in treatment S2 because of photosynthesis of the phytoplankton. Other studies have found similar results for the DO, Chla and $\mathrm{pH}[8]$.

\section{Nutrient Recycling for Aquaculture System}

Nutrient recycling was studied by assessing the distributions of $\mathrm{N}$ and $\mathrm{P}$ in the aquaponics system, and the results are shown in Fig. 4. Significant differences were detected in the fraction of $\mathrm{N}$ remaining in the water and in the $\mathrm{N}$ lost from the water $(P<0.05)$. There were significant differences in the $\mathrm{P}$ lost from the aquaculture water and the shrimp $(P<0.05)$. Regularly inoculating the aquaculture water with Chlorella pyrenoidosa did not change the distribution of $\mathrm{P}$ but increased the loss of $\mathrm{N}\left(\mathrm{NH}_{3}, \mathrm{~N}_{2} \mathrm{O}, \mathrm{N}_{2}\right.$ et al.) from $14.2 \%$ to $25.6 \%(P<0.05)$ and decreased the $\mathrm{N}$ content of the aquaculture water from $16.8 \%$ to $5.2 \%(P<0.05)$. Planting water spinach in treatment $\mathrm{S} 1$ removed $17.2 \% \mathrm{~N}$ and $25.0 \% \mathrm{P}$, and there was less detritus than in S0. This indicated that planting a floating bed system of water spinach can dramatically improve the utilization of feed and the quality of the water. In treatment $S 3$, the removal rates of $\mathrm{N}$ and $\mathrm{P}$ were similar to that of $\mathrm{S} 1$, whereas the $\mathrm{N}$ and $\mathrm{P}$ fractions from the detritus in treatment S3 were significantly lower than in S0 and S1 $(P<0.05)$. Furthermore, the levels of $\mathrm{N}$ and $\mathrm{P}$ absorbed by the shrimp were $43.1 \%$ and $39.4 \%$, respectively. The results demonstrate that combining water spinach and Chlorella pyrenoidosa improves the quality of the water and increases $\mathrm{N}$ and $\mathrm{P}$ utilization. Zhen et al. [23] reported that gaseous nitrogen losses accounted for $51.2 \%$ and $57.3 \%$ of total output in tomato and pakchoi based aquaponics, respectively. Whereas Thakur and Lin [5] claimed that gaseous nitrogen losses accounted for 5.2-36.0\% of nitrogen input in an intensive aquaculture system and thought that denitrification was the main reason. The growth of denitrifying and nitrifying bacteria requires sufficient surfaces where exopolymeric substances are secreted to protect them [23]. Thus, the roots of 
the water spinach have a large surface area for the nitrification and denitrification bacteria inhabiting an aquaponic system. In addition, in the present study,
$20 \%-30 \%$ of $\mathrm{N}$ loss from others included $\mathrm{N}_{2}$ and $\mathrm{N}_{2} \mathrm{O}$ emissions as well as $\mathrm{NH}_{3}$ volatilization in the $\mathrm{S} 2, \mathrm{~S} 3$ and S4 treatments groups.

\section{S0-Nitrogen distribution}

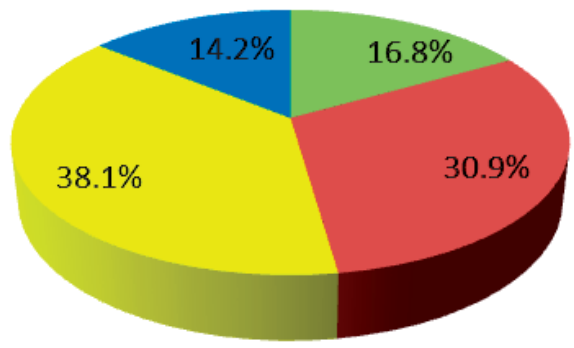

S1-Nitrogen distribution

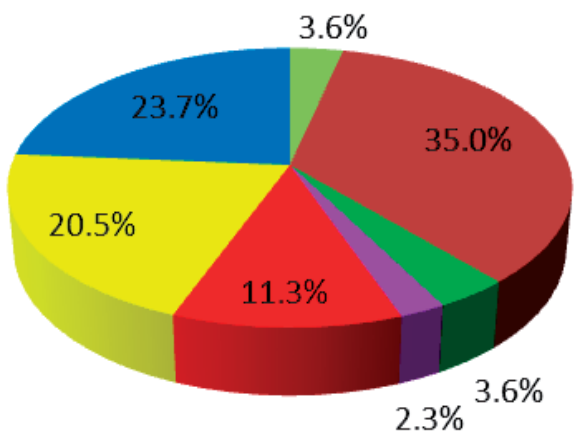

S2-Nitrogen distribution

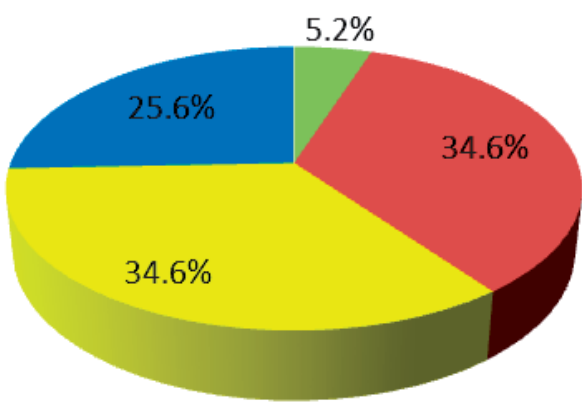

S3-Nitrogen distribution

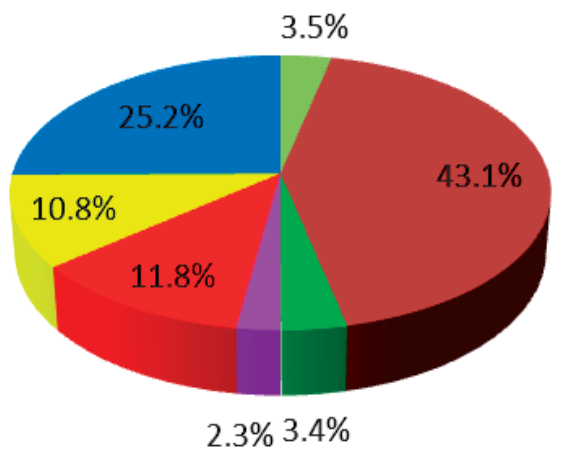

- Aquaculture water

- Penaeus Vanmamei

$\square$ Detrius

n Others

Aquaculture water

- Penaeus Vanmamei

- Water spinach leaf

- Water spinach stem

- Water spinach root

Detrius

n Others

Aquaculture water

- Penaeus Vanmamei

Detrius

n Others

Aquaculture water

- Penaeus Vanmamei

- Water spinach leaf

- Water spinach stem

- Water spinach root

Detrius

- Others

\section{S0-Phosphorus distribution}

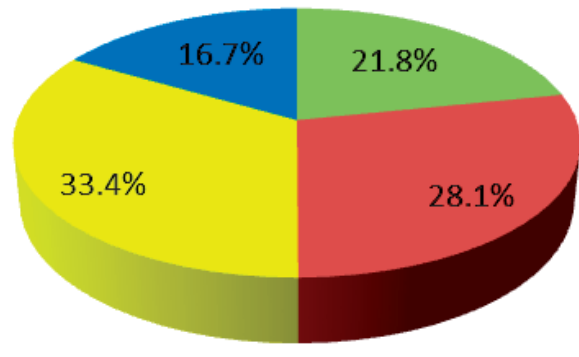

S1-Phosphorus distribution

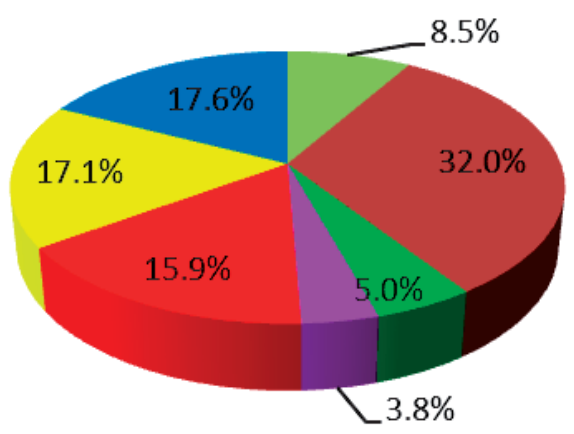

S2-Phosphorusdistribution

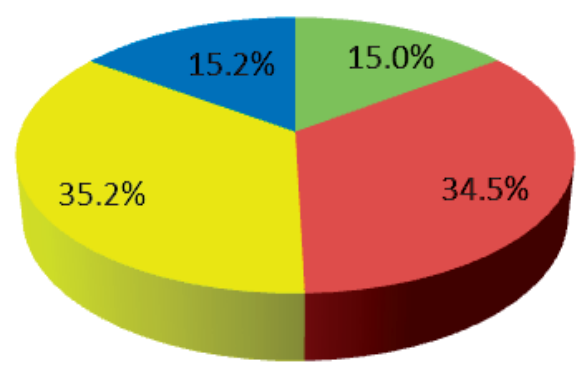

S3-Phosphorusdistribution

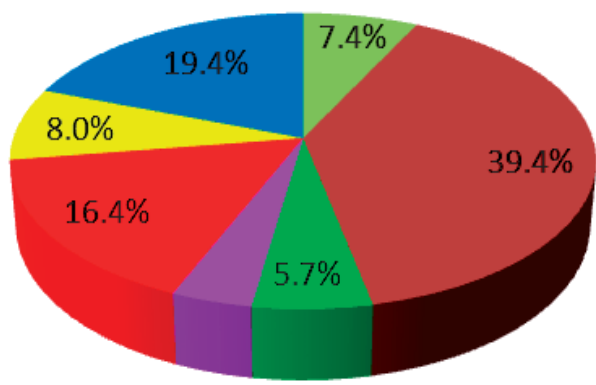

$3.9 \%$

Fig. 4. Nitrogen and phosphorus distributions in different treatments. 


\section{Conclusion}

Floating beds of water spinach and Chlorella pyrenoidosa were used to improve the water quality of shrimp ponds. The removal mechanism of $\mathrm{N}$ and $\mathrm{P}$ was mainly assimilation by microorganisms and absorption by plants, particularly by their roots. The results showed that either water spinach or Chlorella pyrenoidosa can maintain good water quality which improves the immunity of Penaeus vannamei thus reducing the risk of disease outbreaks and improving their growth rate. The combination of water spinach and Chlorella pyrenoidosa can be applied to shrimp farming due to the formation of similar biological floccules around the roots. Such an aquaculture mode of plant-microalgaeshrimp can be used as a multi-pronged approach to improve the economic and environmental benefits of commercial shrimp production.

\section{Acknowledgments}

This work was financially supported by National Research and Development Projects of China (No 2019YFD0900302), Zhejiang Key Research and Development Projects (No 2019C02047) and Zhejiang Basic Public Welfare Research Program (LGN20C190004).

\section{Conflict of Interest}

The authors declare no conflict of interest.

\section{References}

1. FAO (Food and Agriculture Organization of the United Nations). The State of World Fisheries and AquacultureMeeting the Sustainable Development Goals. Sofia. Rome, 2018.

2. Natural Bureau of Statistics of China (2008-2016)): China Fishery Statistic Year-book. Chinese Statistic Press. http:// www.stats.gov.cn

3. SCHWITZGUÉBEL J.P., WANG H. Environmental impact of aquaculture and countermeasures to aquaculture pollution in China. Environmental Science and Pollution Research, 14 (7), 452, 2007.

4. THAKUR D.P., LIN C.K. Water quality and nutrient budget in closed shrimp (Penaeus monodon) culture systems. Aquaculture Engineering, 27 (3), 159, 2003.

5. SUÁREZ-ABELENDA M., FERREIRA T., CAMPSARBESTAIN M., RIVERA-MONROY V.H., MACÍAS F. The effect of nutrient-rich effluents from shrimp farming on mangrove soil carbon storage and geochemistry under semi-arid climate conditions in northern Brazil. Geoderma, 213 (1), 551, 2014.

6. MUANGKEOW B., IKEJIMA K., POWTONGSOOK S., YI Y. Effects of white shrimp, Litopenaeus vannamei (Boone), and Nile Tilapia, Oreochromis niloticus L., stocking density on growth, nutrient conversion rate and economic return in integrated closed recirculation system. Aquaculture, 269, 363, 2007.

7. ZHOU Y., YANG H., HU H., LIU Y. MAO Y., ZHOU H. Bioremediation potential of the macroalgae Gracilaria lemaneiformis (Rhodophyta) integrated into fed fish culture in coastal waters of North China. Aquaculture, 252 (2-4), 264, 2006.

8. RAY A.J., DILLON K.S., LOTZ J.M. Water quality dynamics and shrimp (Litopenaeus vannamei) production in intensive, mesohaline culture systems with two levels of biofloc management. Aquaculture Engineering, 45 (3), 127, 2011.

9. WU Q., HU Y., LI S., PENG S., ZHAO H. Microbial mechanisms of using enhanced ecological floating beds for eutrophic water improvement. Bioresource Technology, 211, 451, 2016.

10. LI M., WU Y.J., YU Z.L., SHENG G P., YU H.Q. Enhanced nitrogen and phosphorus removal from eutrophic lake water by Ipomoea aquatica with low-energy ion implantation. Water Research, 43, 1247, 2009.

11. CHANG Y., WANG W., LIU X., DU F., YAO D. Effects of different pond aquaculture systems on water environments, and suggestions for structural adjustments. Polish Journal of Environmental Studies. 29 (1), 571, 2020.

12. HU Z., LEE J.W., CHANDRAN K., KIM S., BROTTO A.C., KHANAL S.K. Effect of plant species on nitrogen recovery in aquaponics. Bioresource Technology, 188, 92, 2015.

13. WANG C.Y., DAVID J.S., SUSAN D.D., THOMAS J.G. Floating treatment wetland nutrient removal through vegetation harvest and observations from a field study. Ecological Engineering, 78, 15, 2015.

14. BALOI M., ARANTES R., SCHVEITZER R., MAGNOTTI C., VINATEA L. Performance of Pacific white shrimp Litopenaeus vannamei raised in biofloc systems with varying levels of light exposure. Aquaculture Engineering, 52, 39, 2013.

15. ISABELA P., RAFAEL A., CARLOS M.E.S., FELIPE N.V., KATT R.L., LUCIANO V.G., ROSEANE F., JORGE L.B., WALTER Q.S. Production of the halophyte Sarcocornia ambigua and Pacific white shrimp in an aquaponic system with biofloc technology. Ecological Engineering, 100, 261, 2017.

16. CRAB R., DEFOIRDT T., BOSSIER P., VERSTRAETE W. Biofloc technology in aquaculture: beneficial effects and future challenges. Aquaculture, 4, 351, 2012.

17. EMERENCIANO M., BALLESTER E.L.C., CAVALLI R.O., WASIELESKY W. Biofloc technology application as a food source in a limited water exchange nursery system for pink shrimp Farfantepenaeus brasiliensis (Laterille, 1817). Aquaculture Research, 43 (3), 447, 2012.

18. AVNIMELECH Y. Biofloc Technology-A Practical Guide Book, $3^{\text {rd }}$ ed. The World Aquaculture Society: Baton Rouge, Louisiana, EUA, pp. 64, 2009.

19. LIANG J.Y., CHIEN Y.H. Effects of feeding frequency and photoperiod on water quality and crop production in a tilapia-water spinach raft aquaponics system. International Biodeterioration \& Biodegradation, 85, 693, 2013.

20. SUMETH W., ZHEN H., KARTIK C., JAE W.L., Samir K.K. Nitrogen transformations in aquaponic systems: A review. Aquaculture Engineering, 76, 9, 2017.

21. INSELSBACHER E., WANEK W., STRAUSS J. A novel ${ }^{15} \mathrm{~N}$ tracer model reveals: plant nitrate uptake governs nitrogen transformation rates in agricultural soils. Soil Biology \& Biochemistry, 57, 301, 2013. 
22. FINK M., FELLER C. An empirical model for describing growth and nitrogen uptake of white cabbage (Brassica oleracea var. capitata). Scientia Horticulturae. 73 (2-3), 75, 1998.
23. HU Z., LEE J. W., CHANDRAN K., KIM S., SHARMA K., KHANAL S.K. Influence of carbohydrate addition on nitrogen transformations and greenhouse gas emissions of intensive aquaculture system. Science of the Total Environment, 470-471, 193, 2014. 